reaching the aorta through the coarctation, the ductus, and collateral vessels to be pumped caudally. When the final observations were made the more usual femoral flow synchronous with systole presumably resulted from intervening dilatation of the ductus. Expiration induced femoral flow may be useful as an indicator of ductal closure in coarctation.

We thank Professor P W Walton of this University for advice concerning Doppler mechanisms and Professors C A Smith, G S Dawes, and $\mathrm{K}$ W Cross for help in elucidating problems of intrathoracic pressure changes in neonates.
References

1 Milner AD, Saunders RA, Pressure and volume changes during the first breath of human neonates. Arch Dis Child 1977;52:918-24.

2 Altmann PL, Dittmer DS. Respiration and circulation. Federation of American Societies for experimental biology: Bethesda, 1971:86.

Correspondence to Professor B McNicholl, University College, Galway, Eire.

Received 19 May 1983

\title{
Serum thyroxine and thyroid stimulating hormone values in unreferred children with short stature
}

\author{
G V VIMPANI, A F VIMPANI, J W FARQUHAR, AND J SETH \\ The Department of Child Life and Health, University of Edinburgh and the Royal Infirmary, Edinburgh
}

SUMMARY Of 449 children aged 6-9 years with heights below the first centile in a total population of 48221 , only 1 had previously undiagnosed hypothyroidism. In a community with well developed health services hypothyroidism is unlikely to be the cause of short stature among primary school children.

Primary hypothyroidism has been described as the commonest endocrine cause of short stature. ${ }^{1}$ This was tested in a total population study designed to find the prevalence of growth hormone deficiency.

\section{Subjects and methods}

The screening of height in this group has been described. ${ }^{2} 3$ Many children were excluded because of previous negative studies (10), previous diagnosis of an organic cause (82), insufficient residual blood (6), and parental refusal (77). Two hundred and sixty seven children had thyroxine (T4) and 274 thyroid stimulating hormone (TSH) estimations. Serum T4 and TSH values were determined by radioimmunoassay with between assay coefficients of variation of 11.7 and 5.1 percent respectively. Bone age was determined by radiographic examination of the left wrist.

\section{Results}

Serum T4. The distribution of T4 concentrations is shown in Table 1. Values did not differ appreciably in boys and girls (mean (SD) $116.5(21.4) \mathrm{nmol} / \mathrm{l}$ $(9 \cdot 1(1 \cdot 7) \mu \mathrm{g} / \mathrm{dl})$ and $118 \cdot 3(17 \cdot 9) \mathrm{nmol} / \mathrm{l}(9 \cdot 2(1 \cdot 4)$ $\mu \mathrm{g} / \mathrm{dl})$ ). Those with values exceeding $161 \mathrm{nmol} / \mathrm{l} \mathrm{had}$ normal TSH values and were clinically euthyroid.
There was no correlation with sex, age, height, or bone age. Six children had values in the lower range for normal adults $(75-80 \mathrm{nmol} / \mathrm{l})$ and of these, 2 were being treated for coeliac disease. Another had a marginally raised TSH $(7.3 \mathrm{mU} / 1)$, the upper limit of normal being $5.7 \mathrm{mU} / \mathrm{l}$. He had been a 'light for dates' twin, of 42 weeks' gestation, and of below average intelligence. He was clinically euthyroid.

Serum TSH values. The distribution of TSH values shown in Table 2 approximates to that of a $\log$ normal curve.

One 7 year old girl had a value of $98.4 \mathrm{mU} / 1$. Her parents were small. One paternal relative had thyrotoxicosis and 2 others were type I diabetics. Her hair was dry and she was often sleepy but there were no other features and her IQ was 107 (Wechsler intelligence scale). Bone age was 3 years retarded

Table 1 Distribution of serum thyroxine (T4) values in 267 children aged 6-9 years

\begin{tabular}{lccc}
\hline Serum thyroxine (nmol/l) & Boys & Girls & Total \\
\hline$<70$ & - & - & - \\
$71-80$ & 5 & 1 & 6 \\
$81-90$ & 9 & 7 & 16 \\
$91-100$ & 22 & 8 & 30 \\
$101-110$ & 29 & 22 & 51 \\
$111-120$ & 28 & 24 & 52 \\
$121-130$ & 28 & 27 & 55 \\
$131-140$ & 12 & 14 & 26 \\
$141-150$ & 13 & 7 & 20 \\
$151-160$ & 2 & 3 & 5 \\
$>161^{*}$ & 5 & 1 & 6 \\
\hline Total & 153 & 114 & 267 \\
\hline
\end{tabular}

Conversion: SI to traditional units-thyroxine $1 \mathrm{nmol} / 1 \approx 0.08 \mu 1 / \mathrm{dl}$. *Five children had T4 values $>162 \mathrm{nmol} / \mathrm{l}$ and were clinically euthyroid. Their T4 and TSH values (TSH normal value $\approx 2.2 \mathrm{mU} / \mathrm{l}$ ), were; $170(3 \cdot 7), 172(2 \cdot 0), 175(4 \cdot 3), 190(5 \cdot 1)$, and $210(5 \cdot 4)$. 
Table 2 Distribution of thyroid stimulating hormone (TSH) values among boys and girls aged 6-9 years

\begin{tabular}{lccc}
\hline TSH $(m U / l)$ & Boys & Girls & Total \\
\hline$<0.9$ & 1 & 1 & 2 \\
$1 \cdot 0-2 \cdot 9$ & 68 & 50 & 118 \\
$3 \cdot 0-4 \cdot 9$ & 66 & 44 & 110 \\
$5 \cdot 0-6 \cdot 9$ & 15 & 17 & 32 \\
$7 \cdot 0-8 \cdot 9$ & 5 & 5 & 10 \\
$>9.0$ & 0 & 2 & 2 \\
\hline
\end{tabular}

and the patella showed multicentre ossification sites suggesting that hypothyroidism dated from age 5 or 6 years. The thyroid scan showed low iodine uptake. Of the 11 children with TSH values greater than $7.0 \mathrm{mU} / 1,1$ with a TSH value of $7.2 \mathrm{mU} / 1$ and T4 value of $126 \mathrm{nmol} / \mathrm{l}$ also had an indifferent human growth hormone response $(9.5 \mathrm{mU} / \mathrm{l})$ to insulin hypoglycaemia. Another child had a $\mathbf{T}_{4}$ value of $76 \mathrm{nmol} / \mathrm{l}$ but like the remaining 9 was otherwise clinically normal. The TSH concentrations in boys and girls were similar (mean (SD) $3.38(1.44) \mathrm{mU} / 1$ and $3.63(1.70) \mathrm{mU} / 1$ respectively). There was no significant correlation with sex, age, height, or bone age.

\section{Discussion}

The diagnosis of only 1 child with previously undiagnosed hypothyroidism in a very large epidemiological study of 6-9 year old children refutes the belief that hypothyroidism is the commonest cause of short stature in this age group in a population with well developed health services. It does, however, prove that onset and progress may be so insidious that hypothyroidism may escape notice especially when it occurs after the routine examination at school entry that includes the recording of height in centiles. It is likely given the knowledge from neonatal screening that about 1 baby in 4000 has congenital hypothyroidism, and that some children in the 48221 screened were receiving thyroxine and had heights above the first centile.

Although associations between coeliac disease and diabetes mellitus and between diabetes and auto immune thyroiditis are recognised, we do not know of any published reports linking coeliac disease and hypothyroidism. The finding of borderline low values for T4 in the 2 coeliac children in this study was not associated with TSH abnormality and in these cases this excludes primary hypothyroidism but not perhaps some disturbance of thyroid binding globulin.

\section{References}

1 Zachmann M. Diagnosis of treatable types of short and tall stature. In: Barltrop D, ed. Paediatrics and growth. (Unigate Paediatric Workshop No. 5). Fellowship of Postgraduate Medicine, 1978: 121-32.

2 Vimpani GV, Vimpani AF, Lidgard GP, Cameron EHD, Farquhar JW. Prevalence of severe growth hormone deficiency. $\mathrm{Br}$ Med J 1977; ii: 427-30.

3 Vimpani GV, Vimpani AF, Pocock SJ, Farquhar JW. Differences in physical characteristics, perinatal histories and social backgrounds between children with growth hormone deficiency and constitutional short stature. Arch Dis Child 1981 ; 56: 922-8.

Correspondence to Professor J W Farquhar, Department of Child Life and Health, University of Edinburgh, 17 Hatton Place, Edinburgh EH9 1 UW.

Received 18 May 1983

\title{
Human chorionic gonadotrophin secreting pineal germinoma and precocious puberty
}

\author{
S R AHMED, S M SHALET, D A PRICE, AND D PEARSON
}

Departments of Endocrinology and Radiotherapy, Christie Hospital, Manchester and Department of Paediatrics, Royal Manchester Children's Hospital

SUMMARY A $10 \frac{1}{2}$ year old boy presented with raised intracranial pressure and precocious puberty caused by a human chorionic gonadotrophin (HCG) secreting pineal germinoma. After craniospinal irradiation he improved clinically and his HCG concentration fell to an undetectable value. Two years later he remains well. Pineal germinomas are highly radiosensitive obviating the need for difficult surgery associated with high mortality.
Precocious puberty in boys may be caused by pineal tumours. Premature sexual development has been variously attributed to activation of hypothalamic centres initiating pubertal development, tumour involvement of hypothalamic centres that normally inhibit sexual development, loss of a pineal antigonadotrophic factor, or the production of a gonadotrophin by the tumour. Secretion of human chorionic gonadotrophin (HCG) by pineal tumours has been reported in 5 patients, ${ }^{1-4} 2$ of whom 